\title{
Critical Infrastructure, Terrorism, and the Chemical Facility Anti-Terrorism Standards: The Need for Collaboration
}

\author{
Maria Rooijakkers and Abdul-Akeem Sadiq* \\ School of Public and Environmental Affairs, \\ Indiana University-Purdue University Indianapolis \\ 801 West Michigan Street, BS 4070 \\ Indianapolis, IN 46202-5125, USA \\ Email: mrooijak@iupui.edu \\ Email: asadiq@iupui.edu \\ *Corresponding Author
}

\begin{abstract}
In response to $9 / 11$ and the increasing concerns over chemical sector security, Congress gave the Department of Homeland Security (DHS) the authority to regulate the safety and security of U.S. chemical facilities. In April of 2007, DHS passed the interim final rule called the Chemical Facility Anti-Terrorism Standards (CFATS) in order to secure the U.S. chemical infrastructure. Unfortunately, the latest update on CFATS progress by DHS indicated that very few chemical facilities have completed the CFATS process. The slow implementation of CFATS perpetuates the inherent vulnerabilities of U.S. chemical infrastructure and does not augur well for the safety and security of the U.S. population. We argue that collaboration between DHS and the chemical industry can help to speed up CFATS and that communities should not wait for CFATS to ramp up before developing preparedness and response plans in anticipation of future chemical disasters.
\end{abstract}

Keywords: chemical infrastructure security; Chemical Facility Anti-Terrorism Standards; terrorism; collaboration; emergency management; homeland security.

Biographical notes: Maria Rooijakkers is an MPA student at the School of Public and Environmental Affairs at Indiana University Purdue University Indianapolis.

Dr. Abdul- Akeem Sadiq is an assistant professor in the School of Public and Environmental Affairs at Indiana University Purdue University Indianapolis. He teaches undergraduate and graduate courses in emergency management, public safety management, and terrorism. 


\section{Introduction}

The chemical sector is a vital part of the U.S. economy; it makes up approximately 1.9 per cent of U.S. Gross Domestic Product (GDP) and it is the nation's greatest exporter (Spellman and Bieber, 2009). In addition, the chemical sector contributes to the products of many other sectors of the economy including the manufacturing of automobiles, pharmaceuticals, and agricultural products, amongst others. According to KPMG (2010), the U.S. chemical industry directly employs 800,000 people and is responsible for another 5.5 million jobs that are supported indirectly through related activities. As an important player in the U.S. economy, the chemical industry is also considered one of the critical infrastructures, as stated in the National Infrastructure Protection Plan (NIPP) (2009). Critical infrastructure, more specifically, is any material asset that is essential to the operations of an economy and government (Spellman and Bieber, 2009). Critical infrastructure thus span many sectors, including agriculture, banking and finance, chemical materials, transportation, etc. What distinguishes the chemical industry from some of the other critical infrastructure sectors in the United States is that it is considered vulnerable, i.e. it can be exploited to cause harm to society and the system in general (Lippin et al, 2006; Spellman and Bieber, 2009).

To make matters worse, the vulnerabilities of U.S. chemical sector are exacerbated by the close proximity of some chemical facilities to highly populated areas. For example, a study conducted by the Center for American Progress notes that "More than 80 million Americans live within range of a catastrophic chemical release from at least one of the 101 most hazardous chemical facilities" (Orum, 2008 p 3). Perhaps, as a result of these vulnerabilities, terrorists are interested in attacking this sector (Department of Justice (DOJ), 2000). Terrorists may either attack a chemical facility directly with the goal of causing destruction to the facility and 
surrounding communities or with the goal of stealing chemicals that would be used to carry out attacks elsewhere (Stephenson, 2005; Schierow, 2006). In recognition of the possibility of chemical attacks against the chemical sector, the federal government has taken some steps to reduce the risk of chemical terrorism (Spellman and Bieber, 2009) by creating planning scenarios and passing some regulations. For example, four of the fifteen National Planning Scenarios are related to chemical attacks (Howe, 2004). Regulations to prevent terrorist attacks on U.S. chemical facilities include, but are not limited to, the Chemical Facility Anti-Terrorism Standards (CFATS). While CFATS is a good idea conceptually, its implementation is fraught with many problems according to an internal review done by Infrastructure Security Compliance Division (ISCD) (Sadiq and McCreight, 2013). One perturbing problem which Congress, the chemical industry, industry trade associations, etc., agree on is the slow pace of CFATS implementation (Sadiq, forthcoming). Since 2007, ISCD has assigned 3,468 facilities to their final tier designations and of these, only 40 have had their plans approved (Beers and Wulf, 2013). Against the backdrop of slow implementation, communities cannot afford to wait for CFATS to ramp up before taking protective action because terrorists might see this security lapse as an opportunity to strike. The terrorist attacks on $9 / 11$ are vivid reminders that terrorists are capable of exploiting vulnerabilities. This is not to suggest that terrorist attacks pose a greater risk to chemical facilities than other types of hazards. As a matter of fact, accidents and natural hazards, for instance, tend to occur more frequently and result in a greater number of fatalities than terrorist attacks (Viscusi, 2009). In 2012, for example, the Center for Effective Government (2013), reported 1,133 deaths from toxic chemical spills and other accidents. Nonetheless, this 
paper focuses on the threat posed by terrorism and the interim final rule ${ }^{1}$ known as CFATS, which was designed to protect American citizens.

In this paper, we seek to answer two questions. (1) How can DHS speed up CFATS implementation? (2) In the face of slow CFATS implementation, what should communities that have hazardous chemical facilities do in the meantime? To answer these questions, we begin by giving a background on CFATS, including an update on CFATS. Then we describe the problems we are addressing in this paper; namely that CFATS is slow. Next we examine past and foiled chemical terrorism incidents in the U.S. and chemical facility vulnerabilities. This is followed by a discussion on the need for collaboration. Finally, we present our recommendations, conclude with limitations, and outline a future research agenda for the critical infrastructure, homeland security and emergency management communities.

\section{Background on CFATS}

Despite the fact that several members of Congress expressed concern over the security of chemical facilities and hazardous chemicals, it was not until after the tragic events of 9/11 that Congress began taking actions to address these concerns. Prior to the 9/11 terrorist attacks, chemical security was practised on a voluntary basis by the chemical sector, with some organisations like the Society of Chemical Manufacturers and Affiliates (SOCMA) making security a priority for their members (Allmond, 2012). Chemical facilities pose a hazard to homeland security due to the large quantities of chemicals that they store and the potential for

\footnotetext{
${ }^{1}$ An interim Final Rule, according to the National Sustainable Agriculture Coalition, is "a rule promulgated by an administrative agency that goes into effect when it is published, but will be open for public comment for a specific period of time and then potentially revised and issued as a final rule." Accessed http://sustainableagriculture.net/publications/grassrootsguide/glossary/.
} 
release, theft or diversion, and sabotage and contamination of chemicals by terrorists (Shea, 2012). In response to $9 / 11$ and the concomitant increasing concerns over chemical sector security, Congress gave the Department of Homeland Security (DHS) the authority to regulate the security of chemical facilities. In April of 2007, DHS passed the interim final rule called CFATS and gave the ISCD the authority to oversee the programme (Shea, 2012). Furthermore, in 2006, DHS incorporated the chemical sector into the NIPP, which is designed to enhance critical infrastructure safety in the U.S. (NIPP, 2013).

Under the interim final rule, 322 chemicals were designated as "chemicals of interest" (COI). Facilities that hold significant amounts of COI were asked to submit information to DHS, after which DHS determined preliminary risk levels of the facilities. Risk levels range from tier 1 (the highest risk level) to tier 4 (the lowest risk level) (Shea, 2012). Once facilities are designated into tiers, they are asked to submit a Site Security Plan (SSP) or an Alternative Security Plan (ASP). DHS can either approve or reject the submitted SSPs or ASPs. A facility is considered compliant if DHS approved its SSP or ASP and the facility implements the approved SSP or ASP (Beers, 2012).

In November of 2011, an internal document prepared by the Director of ISCD that brought attention to some inherent problems of CFATS was leaked to the public. In this document, it was revealed that ISCD had high turnover in management, low employee morale, issues with compliance inspections, and a lack of support from the Office of Infrastructure Protection (IP) and the National Program and Protection Directorate (NPPD) (Beers, 2012), amongst other problems. As a result of these issues, none of the approximately 4000 SSPs that were submitted had been approved by DHS. In response to these problems and the need to 
address them, DHS developed a 94-item action plan to improve and track its progress (Caldwell, 2012).

In September of 2012, Suzanne Spaulding, the Deputy Under Secretary of NPPD, and David Wulf, Director of NPPD, reported that 68 out of the 94 action items were completed (Spaulding and Wulf, 2012). Furthermore, in March of 2013, it was reported that ISCD had approved 36 tier 1 SSPs and ASPs and four tier 2 SSPs and ASPs (Beers and Wulf, 2013). Despite these improvements, GAO estimates that it will take ISCD another 7 to 9 years to complete tier assignments and review the remaining 3,120 site security plans (Caldwell, 2013).

Shea (2012) has drawn attention to another CFATS problem that is relevant to this paper - the Chemical-terrorism Vulnerability Information (CVI) System. CVI is information that is exempt from disclosure under the Freedom of Information Act (FOIA) and other similar laws (Waugh and Streib, 2006), including the "Emergency Planning Community Right to Know Act" (EPCRA) (Shea, 2012). According to DHS (2008b), both the Security Vulnerability Assessments (SVAs) and the SSPs are considered CVI. This means that only authorised individuals have access to this information. An authorised individual is "any person who has completed DHS online CVI training, which includes obtaining an Authorized User number, or equivalent measures approved by DHS; and complied with any background checks or other requirements for personal identification or trustworthiness that DHS may require under 6 CFR $\S \S 27.400(e)(2)(i i i)$, and 27.400(e)(3)" (DHS, 2008). One issue that arises from CVI is that unauthorised emergency managers will lack important information on the vulnerability of chemical facilities in their communities. This information, which local emergency managers cannot obtain through EPCRA or FOIA, is necessary to properly plan for potential chemical disasters. For example, if a 
chemical disaster were to occur, a lack of access to the SSPs may result in duplication of efforts and consequently, a slow response time.

\section{Chemical Terrorism and Chemical Facility Vulnerabilities}

In this section, past and foiled terrorist attacks involving the use of chemicals in the U.S. is discussed using data from the Global Terrorism Database (GTD) of the National Consortium for the Study of Terrorism and Responses to Terrorism (START), and The Heritage Foundation. We also discuss the exacerbation of U.S. vulnerability resulting from the location of chemical companies near the 10 largest U.S. cities using data from the U.S. Census Bureau and Greenpeace USA.

Table 1 illustrates the number of chemical attacks that have already occurred in the United States between 1970 and 2011. From this table, it is clear that chemical attacks do occur in the U.S. and thus are a real threat to its citizens and critical infrastructures. According to START (2012), there were a total of 1 fatality and 40 injuries sustained by victims of these twelve chemical attacks. While the number of casualties to date appears to be small, there is a possibility that a successful terrorist attack on a large chemical facility could lead to fatalities, destruction, or disruption on a massive scale. For example, according to the National Planning Scenario 6 (Chemical Attack - Toxic Industrial Chemicals) (a hypothetical scenario), if terrorists use toxic industrial chemicals to attack a community, the chemical release can lead to 350 fatalities, 1,000 hospitalisations, contamination of the environment, and billions of dollars in economic loss (Howe, 2012). In addition to this, table 2 demonstrates that there have been several attempts by terrorists to carry out attacks using chemicals since 9/11. Although, these four plots were foiled, they are strong indication that the threat of chemical terrorism is real and ongoing. 
Table 1. Chemical Attacks in the United States: 1970-2012

\begin{tabular}{|c|c|c|c|c|}
\hline Date & Location & Perpetrator & Target Type & Weapon Type \\
\hline $2 / 17 / 2010$ & $\begin{array}{r}\text { Clearwater, } \\
\text { Florida }\end{array}$ & Unknown & Business & Chemical \\
\hline $4 / 3 / 2000$ & $\begin{array}{r}\text { Kansas City, } \\
\text { Missouri }\end{array}$ & Unknown & $\begin{array}{r}\text { Government } \\
\text { (general) }\end{array}$ & Chemical \\
\hline $3 / 22 / 2000$ & Ogden, Utah & Unknown & $\begin{array}{r}\text { Government } \\
\text { (general) }\end{array}$ & Chemical \\
\hline 3/26/1998 & $\begin{array}{r}\text { Marina Del Rey, } \\
\text { California }\end{array}$ & Individual & $\begin{array}{r}\text { Government } \\
\text { (general) }\end{array}$ & Chemical \\
\hline 9/19/1988 & $\begin{array}{r}\text { Los Angeles, } \\
\text { California }\end{array}$ & Up the IRS, Inc. & $\begin{array}{r}\text { Government } \\
\text { (general) }\end{array}$ & $\begin{array}{r}\text { Explosives/Bombs/ } \\
\text { Dynamite, Chemical }\end{array}$ \\
\hline $11 / 26 / 1986$ & $\begin{array}{r}\text { New York City, } \\
\text { New York }\end{array}$ & $\begin{array}{r}\text { Jewish Defense } \\
\text { League (JDL) }\end{array}$ & Business & Incendiary, Chemical \\
\hline $9 / 2 / 1986$ & $\begin{array}{r}\text { New York City, } \\
\text { New York }\end{array}$ & $\begin{array}{r}\text { Jewish Defense } \\
\text { League (JDL) }\end{array}$ & Business & Chemical \\
\hline 2/1978 & Cincinnati, Ohio & $\begin{array}{r}\text { Anti-Abortion } \\
\text { Activists }\end{array}$ & Abortion related & $\begin{array}{r}\text { Explosives/Bombs/ } \\
\text { Dynamite, Chemical }\end{array}$ \\
\hline 9/6/1976 & $\begin{array}{l}\text { Hyattsville, } \\
\text { Maryland }\end{array}$ & Individual & $\begin{array}{r}\text { Private Citizens } \\
\& \text { Property }\end{array}$ & Chemical \\
\hline $1 / 1 / 1976$ & Unknown & Arabs (suspected) & $\begin{array}{r}\text { Government } \\
\quad \text { (general) }\end{array}$ & Chemical, unknown \\
\hline $11 / 6 / 1973$ & $\begin{array}{l}\text { Oakland, } \\
\text { California }\end{array}$ & $\begin{array}{r}\text { Symbionese } \\
\text { Liberation Army } \\
\text { (SLA) }\end{array}$ & $\begin{array}{r}\text { Educational } \\
\text { Institution }\end{array}$ & Firearms, Chemical \\
\hline 3/9/1970 & $\begin{array}{l}\text { Ashville, } \\
\text { Alabama }\end{array}$ & Ku Klux Klan & $\begin{array}{r}\text { Private Citizens } \\
\& \text { Property } \\
\end{array}$ & Chemical, Unknown \\
\hline
\end{tabular}

Source: START. (2012). Global Terrorism Database [Data file]. 
Table 2. Foiled Chemical Terrorist Attacks in the United States: 2001-2013

\begin{tabular}{|c|c|c|c|c|}
\hline Date & Location & Perpetrator & Target Type & Weapon Type \\
\hline $8 / 2011$ & Unknown & $\begin{array}{l}\text { Emerson } \\
\text { Winfield Begolly }\end{array}$ & $\begin{array}{l}\text { Government and } \\
\text { Private Citizens }\end{array}$ & $\begin{array}{l}\text { Explosives, destructive } \\
\text { devices, and weapons } \\
\text { of mass destruction }\end{array}$ \\
\hline $2 / 2011$ & $\begin{array}{l}\text { Lubbock, } \\
\text { Texas }\end{array}$ & $\begin{array}{l}\text { Khalid Ali-M } \\
\text { Aldawsari }\end{array}$ & $\begin{array}{l}\text { Government and } \\
\text { Private Citizens }\end{array}$ & $\begin{array}{l}\text { Improvised Explosive } \\
\text { Device (IED) }\end{array}$ \\
\hline $9 / 2009$ & $\begin{array}{l}\text { New York City, } \\
\text { New York }\end{array}$ & $\begin{array}{l}\text { Najibullah Zazi, } \\
\text { Al-Qaeda }\end{array}$ & Private Citizens & TATP bomb \\
\hline $3 / 2003$ & Unknown & $\begin{array}{l}\text { Uzair and } \\
\text { Saifullah Paracha }\end{array}$ & Unknown & Explosives \\
\hline
\end{tabular}

Source: The Heritage Foundation (2012)

Table 3 shows the number of individuals that could potentially be impacted by high risk chemical plants located near the 10 largest U.S. cities by population, according to the United States Census Bureau and Greenpeace USA. A major implication of Tables 1, 2 and 3 is that chemical weapons have been used or attempted to be used in terrorist attacks in the U.S. and may be used again in the future, especially considering the fact that scores of U.S. chemical facilities are located close to large populations. A successful terrorist attack on a large chemical facility located close to an urban centre would no doubt result in mass casualties and injuries, in addition to considerable damage to infrastructure. As a result of the potential consequence of such an attack, the federal government, the chemical industry, communities, and other stakeholders should be aware of the risks faced by the U.S. chemical industry and take additional steps to safeguard this important sector. 
Table 3. The number of individuals that could potentially be impacted by high risk chemical plants located near the 10 most populated U.S. cities.

\begin{tabular}{|c|c|c|c|}
\hline City & Plant Name & $\begin{array}{l}\text { Vulnerable } \\
\text { Population (in } \\
\text { millions) }\end{array}$ & $\begin{array}{l}\text { Vulnerability } \\
\text { Zone*(in } \\
\text { miles) }\end{array}$ \\
\hline \multicolumn{4}{|c|}{ New York, NY } \\
\hline & Infineum USA L.P. Bayway Chemical Plant & 4.0 & 14 \\
\hline & Kuehne Chemical Co., Inc & 12.0 & 14 \\
\hline & Bayonne Plant Holding L.L.C & 0.11 & 2.13 \\
\hline \multicolumn{4}{|c|}{ Los Angeles, CA } \\
\hline & Silver Lake Chlorination Station & 0.41 & 3 \\
\hline & AMVAC Chemical Corporation & 3.44 & 9.9 \\
\hline & JCI Jones Chemical Inc.-Torrance & 4.54 & 16 \\
\hline & KIK SoCal Inc. & 4.9 & 14 \\
\hline & $\begin{array}{l}\text { Pioneer Americas LLCd/b/a Olin Chlor } \\
\text { Alkali Produc }\end{array}$ & 2.55 & 9.9 \\
\hline \multicolumn{4}{|c|}{ Chicago, IL } \\
\hline & Tyson Foods Inc & 0.11 & 1.7 \\
\hline & Pelron & 1.65 & 8.7 \\
\hline & Dover Chemical Corporation & 1.88 & 14 \\
\hline & Kemira Water Solutions, Inc & 1.49 & 14 \\
\hline & PVS Chemicals Incorporated & 5.07 & 25 \\
\hline & Airgas Specialty Products, INC & 0.30 & 4.4 \\
\hline & Arkema Emulsion Systems & 0.39 & .9 \\
\hline & Rowell Chemical Corporation & 2.0 & 14 \\
\hline & K.A. Steel Chemicals, Inc & 1.41 & 14 \\
\hline & CITGO Petroleum Corporation & 3.1 & 22 \\
\hline & Stepan Company & 1.5 & 25 \\
\hline \multicolumn{4}{|c|}{ Houston, TX } \\
\hline & KIK International LLC & 2.13 & 14 \\
\hline & Akzo Nobel Chemicals Inc. & 1.1 & 12 \\
\hline & Champion Technologies, Inc & .66 & 12 \\
\hline & The Clorox Company & 1.87 & 14 \\
\hline & Rhodia Inc. & 3.45 & 25 \\
\hline & South Houston Wastewater Treatment Plant & 0.14 & 3.1 \\
\hline & Terra Mississippi Nitrogen, Inc & 2.4 & 25 \\
\hline & Pasadena Refining Systems, Inc & 0.65 & 9.3 \\
\hline & East Water Purification Plant & 1.4 & 14 \\
\hline & Agrifos Fertilizer L.L.C. & 3.15 & 25 \\
\hline & Ethyl Corporation & 1.24 & 14 \\
\hline & Arkema Inc. & 2.0 & 16 \\
\hline & ALTIVIA Greens Bayou & 3.4 & 14 \\
\hline & Syngenta Crop Protection, Inc & 1.19 & 14 \\
\hline & DXI Industries, Inc & 1.41 & 16 \\
\hline & Stolt-Nielsen USA Inc. & 0.40 & 8.7 \\
\hline & Occidental Petroleum Corporation & 2.6 & 25 \\
\hline & Delta Petroleum Company & 3.6 & 22 \\
\hline & GEO Specialty Chemicals, Inc & 0.86 & 15 \\
\hline
\end{tabular}




\begin{tabular}{|c|c|c|c|}
\hline & Clean Harbors Environmental Services, Inc & 1.83 & 22 \\
\hline & Momentive Specialty Chemicals Inc & 0.20 & 6.8 \\
\hline & DuPont & 1.6 & 25 \\
\hline & INVISTA S.a.r.l & 1.89 & 25 \\
\hline & Baker Hughes, Inc & 1.12 & 25 \\
\hline & Kaneka Corporation & 2.77 & 25 \\
\hline & Lyondell Chemical Company & 1.15 & 18 \\
\hline & Celanese, Ltd. & 1.4 & 21 \\
\hline \multicolumn{4}{|l|}{ Philadelphia, PA } \\
\hline & Sunoco, Inc & 1.31 & 8.04 \\
\hline & Tanner Industries, Inc & 0.35 & 3.7 \\
\hline & Solvay Solexis, Inc & 4.17 & 25 \\
\hline & PBF Holding Company LLC & 3.17 & 19 \\
\hline & ConocoPhillips & 2.4 & 19 \\
\hline & Honeywell International Inc. & 3.64 & 25 \\
\hline & E.I. Dupont De Nemours and Co., Inc & 2.0 & 25 \\
\hline \multicolumn{4}{|l|}{ Phoenix, AZ } \\
\hline & Hill Brothers Chemical Co. & 1.75 & 14 \\
\hline & DPC Enterprises, L.P. & 1.69 & 14 \\
\hline \multicolumn{4}{|l|}{ San Antonio, TX } \\
\hline & H.E. Butt Grocery Company & 0.18 & 4.8 \\
\hline \multicolumn{4}{|l|}{ San Diego, CA } \\
\hline & City of San Diego Water Department & 0.11 & 2.4 \\
\hline \multicolumn{4}{|l|}{ Dallas, TX } \\
\hline & NTMWD Regional Water Treatment Plant & 2.1 & 25 \\
\hline & Dallas Water Utilities & 2.5 & 25 \\
\hline & Trinity River Authority of Texas & 0.36 & 14 \\
\hline & Dallas Water Utilities & 0.63 & 19 \\
\hline & Central Wastewater Treatment Plant & 1.6 & 14 \\
\hline & North Texas Municipal Water District & 0.15 & 3 \\
\hline & Elm Fork Water Treatment Plant & 1.6 & 14 \\
\hline & Petra Chemical Company & 2.3 & 14 \\
\hline & Bachman Water Treatment Plant & 2.0 & 14 \\
\hline & Trinity River Authority of Texas & 3.93 & 25 \\
\hline & Tyson Foods Inc & 0.13 & 3.6 \\
\hline & Pierce Chemicals/Royal Bond & 0.32 & 5.72 \\
\hline & Southside WWTP & 0.63 & 19 \\
\hline & Tarrant County Water Supply Project & 1.3 & 13.5 \\
\hline & Village Creek Wastewater Treatment Plant & 2.6 & 21 \\
\hline \multicolumn{4}{|l|}{ San Jose, CA } \\
\hline & Air Products and Chemical, Inc & 0.21 & 3.8 \\
\hline & $\begin{array}{l}\text { San Jose/Santa Clara Water Pollution } \\
\text { Control Plant }\end{array}$ & 0.22 & 5.5 \\
\hline
\end{tabular}

*"The size of this zone varies for each facility and ranges from less than a mile to 25 miles. Each zone was determined by the plant owner based on the type and quantity of the toxic chemical on site, local topography and weather patterns." 2

Source: U.S. Census Bureau and Greenpeace USA

\footnotetext{
${ }^{2}$ http://usactions.greenpeace.org/chemicals/map/.
} 


\section{Need for Enhanced Collaboration}

In this section, we discuss the need for collaboration in critical infrastructure, homeland security and emergency management in general and chemical security and CFATS in particular.

According to a working group that consisted of emergency management practitioners and academics, collaboration involves establishing and maintaining "broad and sincere relationships among individuals and organizations to encourage trust, advocate a team atmosphere, build consensus, and facilitate communication" (Blanchard et al, 2007). Collaboration amongst homeland security and emergency management actors provides a solid foundation for mitigating, preparing for, responding to, and recovering from natural and man-made disasters (Waugh and Streib, 2006). In this paper, collaboration is the "mutual agreement to work together on the same task" (Kapucu and Garayev, 2011), whereby the results of the group working together are better than any one member would have accomplished alone.

There is no denying the fact that the federal government is interested in protecting critical infrastructures through public-private partnerships. For instance, Federal Emergency Management Agency (FEMA) Administrator Craig Fugate (2011) said, "We cannot separate out and segment one sector in isolation; the interdependencies are too great.... We want the private sector to be part of the team and we want to be in the situation where we work as a team and not compete with each other". DHS Secretary, Janet Napolitano concurs with Craig Fugate by noting that "programs such as the "If You See Something, Say Something"TM" public awareness campaign and the Nationwide Suspicious Activity Reporting initiative highlight the importance of public-private partnerships in reporting suspicious activity to local law enforcement and underscore that security is a shared responsibility" (DHS, 2011). Public-private partnerships are defined as commitments by governments and private businesses to work together to achieve 
shared objectives for the delivery of public services and infrastructure (World Bank, 2013). The quest for such an important partnership is laudable and if properly done, would be instrumental in safeguarding the U.S. critical infrastructure and establishing an efficient and effective homeland security and emergency management system. There have been some recent efforts by government agencies to build public-private partnerships. FEMA, for example, has made available a public forum where communities can share their collaborative efforts as models for disaster resilience (FEMA, 2012). Despite such efforts to establish collaboration, it is unclear how to establish collaborative ventures between government and the private sector in practise and there are no organisational guidelines for ensuring public-private collaborations (Abou-Bakr, 2013) even though the private sector owns about 85 per cent of the U.S. infrastructure (9/11 Commission Report, 2004).

In the context of chemical security, it is noteworthy that DHS has and is trying to collaborate with industry on some chemical security initiatives. For example, in 2010, DHS launched "CFATS-Share", a web-based information sharing tool that "provides interested state Homeland Security Advisors and their designees, DHS Protective Security Advisors, the National Infrastructure Coordinating Center, the Chemical Sector-Specific Agency, as well as members of the State, Local, Tribal and Territorial Government Coordinating Council access to key details on CFATS facility information as needed" (Beers, 2011). While such collaborative programmes are encouraged, DHS needs to establish specific guidelines on what roles the private sector should play in chemical security in general and CFATS in particular. It may also be beneficial for DHS to turn to other agencies such as the Center for Disease Control and 
Prevention (CDC) and Environmental Protection Agency (EPA) for guidance on how to build public-private partnerships. ${ }^{3}$

All disasters are local (Dynes et al, 1972) and so communities must build their capacity to respond to chemical disasters within their borders because if a chemical release were to occur, the federal government may not be able to marshal its resources for hours or even days (Waugh and Streib, 2006). The National Response Framework (NRF) makes this point very clear by noting that, "Each organization or level of government therefore has an imperative to fund and execute its own core emergency management responsibilities" (DHS, 2008a).

Due to a lack of financial resources, local governments are not able to invest adequately in emergency management programmes. Nonetheless, the repercussions of not taking action to protect citizens from a potential chemical release can be enormous in the form of fatalities, injuries, and environmental degradation. Against this backdrop of insufficient resources at the local level, it is crucial for the local emergency management offices to collaborate with chemical facility owners, local public health departments, and first responders to build the capacity (e.g., through mutual aid agreements and joint exercises) necessary to prepare for, respond to, and recover from future chemical disasters (Waugh and Straub, 2006).

\section{Recommendations}

\subsection{Recommendations for Speeding up CFATS}

If DHS and the chemical industry are able to establish a successful collaborative relationship, they stand to benefit immensely. First, collaboration can lead to trust between DHS and the

\footnotetext{
${ }^{3}$ See http://www.cdcfoundation.org/content/public-private-partnership-policies-and-guidelines and http://www.epa.gov/pesticides/grants/how.htm.
} 
chemical industry (Blanchard et al, 2007) and trust might in turn lead to more transparency from DHS and more compliance from chemical facilities. Second, with collaboration, it may be relatively easier for DHS and chemical facilities to work hand-in-hand to achieve an effective response to chemical disasters (Waugh and Sadiq, 2011; Waugh and Streib, 2006). And finally, collaboration can lead to better coordination of personnel and resources when responding to and recovering from chemical disasters.

Two specific areas where collaboration between DHS and the chemical industry might help to speed up CFATS implementation are as follows. The first area has to do with how the Risk Based Performance Standards (RBPSs) are used to assign chemical facilities to tiers. Sadiq and McCreight (2013) noted that one of the problems of CFATS is a lack of transparency on how chemical facilities are assigned tiers. On this issue, DHS needs to be transparent and also involve the chemical industry in the design of the RBPSs. The involvement and subsequent input of the chemical industry would be instrumental in developing an effective and inclusive RBPS methodology. When the chemical industry knows that the RBPS methodology is inclusive, they are likely to believe in it, abide by it, and agree with the tier assignments that result from it. This will invariably help to move CFATS along quicker.

The second area where DHS and the chemical industry can improve their collaboration with a view to speeding up CFATS implementation is by creating a forum separately or within CFATS-Share where DHS and the chemical industry can share information on lessons learned on CFATS design and implementation. Such a repository for multiple perspectives would benefit both parties. Of particular importance would be the inputs from CFATS compliant facilities who could share information on best practices and problems they encountered during the CFATS process. Furthermore, DHS can share information on the "do's" and "don'ts" of inspections and 
basic information about facilities, without revealing identifying and sensitive information about facilities that have gone through the CFATS process. In so doing, chemical facilities may be able to adapt the lessons and best practices to fit their specific needs and in the process, help to speed up CFATS.

In order for these specific recommendations to work, we suggest that Congress include a mandate within CFATS that will require DHS to collaborate with the chemical industry in both the design of CFATS (e.g., the use of the RBPS methodology to assign chemical facilities to tiers) and the implementation of CFATS (e.g., during inspections). Such a mandate, which is currently non-existent, would allow DHS to invest in meaningful collaborative initiatives with the chemical industry, thus speeding up CFATS.

\subsection{Recommendations for Helping Communities to Improve Their Capacities to Deal with Chemical Disasters}

We recommend that communities with chemical facilities must be prepared for a potential terrorist attack against their chemical facilities by including provisions for planning for chemical emergencies within their Comprehensive Emergency Management Plans (CEMPs) or Emergency Operation Plans (EOPs). For instance, a provision might include the purchase of Personal Protective Equipment (PPE) and breathing apparatuses. Two main obstacles face communities when they try to develop specific provisions for chemical emergencies within their CEMPs or EOPs -a lack of CVI about the chemical facilities that are located in their communities and a lack of funding. An important ingredient in crafting a good plan is gathering information about the type and quantities of toxic chemicals present in these chemical facilities, as well as measures in place in these facilities to deal with chemical releases. Unfortunately, such information is classified as CVI and is not readily available to the public. As said earlier, 
communities through their Local Emergency Planning Commissions (LEPC) cannot obtain CVI by invoking EPCRA under the Superfund Authorization and Reauthorization Act (SARA) (Perry and Lindell, 2006). Having no access to CVI has negative implications for the communities harbouring chemical facilities. For example, without adequate knowledge of the type and quantities of chemicals present in a chemical facility that is ablaze, it would be difficult for fire fighters to know the appropriate strategy to adopt in putting out the fire (Sadiq and McCreight, 2013). Similarly, if chemical facilities do not divulge information about their chemicals and their response capabilities or response plans for chemical disasters, it will be difficult for local emergency managers to include measures in their CEMPs or EOPs in readiness for a potential chemical disaster. The authors understand the need for chemical facilities to withhold sensitive information from the public. However, there is a commensurate need to balance this security concern with capacity development for potential chemical disasters. As a result, we suggest that local emergency managers should obtain CVI certification and CVI training. To obtain CVI certification and CVI training, local emergency managers would need to seek approval from the DHS inspector(s) attached to the chemical facilities from which they want the CVI (DHS, 2012). In addition, it is important to increase communication between DHS, and in particular CFATS inspectors, the chemical industry, and local emergency managers. This can be achieved through regular meetings, webinars, or even conferences. These avenues could help to provide updates regarding chemical security issues and foster improved communication, trust, and collaboration amongst these important players.

The other obstacle facing communities when planning for potential chemical disasters is a lack of funding. With dwindling funds and competition from other areas like education, health care, public works, etc., there is need for communities to augment their funds through 
government grants. For example, qualified communities should seek funding from the federal government through the Urban Areas Security Initiative (UASI) programme. States that have chemical facilities that could cause catastrophic damage if attacked by terrorists may also be able to get funding from the State Homeland Security Program (SHSP). Furthermore, in the face of modicum funds, local emergency management offices can partner with local public health departments, non-governmental organisations, and chemical facilities to raise funds needed to prepare for and respond to future chemical disasters. Finally, there may be funding available through private ventures. Communities should seek support -financial, logistic, etc. - from private entities located in their communities. There is evidence that the private sector has provided much needed help after major disasters in the U.S. For instance, Verizon Corporation donated over 5,000 cell phones to emergency responders after the 9/11 terrorist attacks, WalMart shipped 2,498 trailers worth of merchandise to those in need after Hurricane Katrina, and a number of companies, including Hess, Johnson \& Johnson, Apple, and Microsoft, donated a total of \$126.6 million for disaster relief and recovery following Superstorm Sandy (Abou-Bakr, 2013; Simmins, 2012). The important role that the private sector played in the aftermaths of the 9/11 terrorist attacks, Hurricane Katrina, and more recently, Superstorm Sandy is an indication that the private sector's huge resources can help communities respond to and recover from disasters.

We therefore, suggest that community leaders, and in particular, local emergency managers explore avenues whereby public-private partnerships could be leveraged to mitigate, prepare for, respond to, and recover from disasters, including chemical terrorism and chemical accidents (e.g., the 2013 fertiliser plant explosion in West Texas). Community leaders can take a 
cue from FEMA's public-private partnership programmes that educate and train the private sector so that they are prepared when disaster strikes (see http://www.fema.gov/private-sector).

\section{Conclusion}

From the foregoing, it is clear that the U.S. chemical industry is not only vulnerable to terrorist attacks but that some chemical facilities are located near highly populated areas. Perhaps, it is due to these two factors -wholly or partially- that terrorists are interested in attacking U.S. chemical facilities on our homeland. The argument that such an attack may be far-fetched seems legitimate especially when we look at the frequency of chemical attacks relative to natural disasters and technological accidents in the U.S. Some might even argue that the small number of chemical attacks against the U.S. chemical infrastructure is as a result of the security in place at U.S. chemical facilities and the tireless efforts of local, state, and federal law enforcement officials (as was the case of the four foiled chemical attacks in Table 2).

The realisation by Congress that there have been some terrorist attacks against chemical facilities on U.S. soil in the past and that the U.S. chemical sector is vulnerable to terrorist attacks, led to Congress passing CFATS. Unfortunately, CFATS stakeholders -Congress, chemical industry, public, trade association, etc. -have noted that CFATS implementation is very slow and the latest update on CFATS progress by DHS reports at best, a modest pace of CFATS implementation. The slow implementation of CFATS does not augur well for public safety, the safety of U.S. critical infrastructure, the U.S. economy, and national security, especially given that a successful attack on a large chemical facility located within a 25 -mile radius of any of the 10 most populous U.S. cities could be catastrophic. 
This paper addresses two questions. First, "how can DHS speed up CFATS implementation?" Second, "in the face of slow CFATS implementation, what should communities that have hazardous chemical facilities do in the meantime?" We argue that collaboration with the chemical industry on both the design and implementation of CFATS can help to speed up CFATS and recommend that Congress should include specific requirements within CFATS that would compel DHS to collaborate with the chemical industry on both the design and implementation of CFATS. We also recommend that communities with chemical facilities must be prepared for a potential terrorist attacks against their chemical facilities by including provisions for planning for chemical emergencies within their CEMPs or EOPs. Two main obstacles face communities when they try to develop special provisions for chemical emergencies within their CEMPs or EOPs - a lack of CVI about the chemical facilities that are located in their communities and a lack of funding. We recommend that local emergency managers get CVI certification and also collaborate with local public health departments, private entities, and non-profit organisations to raise funds and build the capacity needed to mitigate, prepare for, respond to, and recover from potential chemical disasters.

There are several limitations to our analysis. First, our paper focuses primarily on the slow implementation of CFATS by DHS and thereby ignores many of the other CFATS problems - organisational culture, employee morale, and administrative issues- that were made known in the ISCD internal report that was leaked in 2011 (Beers, 2012). The consideration of these issues in research could help shed light on how and why the resolution of these problems could improve CFATS. Another limitation is that the Global Terrorism Database does not include information on failed attempts or provide information on terrorist attacks that may have occurred in 2013. Similarly, we were only able to find information on foiled chemical terrorist 
attacks in the U.S. from Heritage Foundation from 2001 to 2013. Based on these limitations and the newness of CFATS, there are a myriad of questions that homeland security, emergency management, and critical infrastructure researchers can explore. For instance, researchers should examine the effectiveness of CFATS assessment tools (e.g. Chemical Security Assessment Tool) and the RBPSs. In addition, researchers should examine CFATS-Share more closely to determine how it can be better utilised to increase collaboration between DHS and the chemical industry. Despite the limitations of this paper, the authors hope that this paper will help to stimulate discussions and spur research in the homeland security, emergency management, and critical infrastructure communities with the goal of speeding up CFATS and contributing to the safety of the chemical industry and the country as a whole.

\section{Acknowledgements}

The authors thank the School of Public and Environmental Affairs (SPEA) Deans Council for providing the funds for this study. The authors are also grateful to Fred Webber for his insights on this study. The opinions expressed in this paper are those of the authors and do not represent the views of SPEA Deans Council or SPEA.

\section{References}

Abou-Bakr, A.J. (2013) Managing disasters through public-private partnerships. Washington, DC: Georgetown University Press.

Allmond, W.E. (2012) “The Chemical Facility Anti-Terrorism Standards program: addressing its challenges \& finding a way forward." Testimony before the House Committee on Homeland Security, Subcommittee on Cybersecurity, Infrastructure Protections, \& Security Technologies.

Associated Press. (2005) "Study: 100 chem plants could be terror targets: lethal chemicals stored near most populous U.S. areas, report finds." NBCnews.com.

http://www.nbcnews.com/id/8477697/ (Accessed on February 20, 2013). 
Beers, R. (2012) "Evaluating internal operation and implementation of the Chemical Facility Anti-Terrorism Standards Program (CFATS) by the Department of Homeland Security." Testimony before the House Committee on Energy and Commerce, Subcommittee on Environment and the Economy.

Beers, R. (2011) "H.R. 908, a bill to extend the authority of the Secretary of Homeland Security to maintain the Chemical Facility Anti-Terrorism Standards (CFATS) Program." Testimony before the House Committee on Energy and Commerce.

Beers, R. and Wulf, D. (2013) Statement for the record before the Committee on Energy and Commerce, Subcommittee on Environment and the Economy, United States House of Representatives.

Blanchard, W.B., Canton, L.G., Cwiak, C.L., Goss, K.C., McEntire, D.A., Newsome, L., Selves, M.D., Sorchik, E.A., Stenson, K.,Turner, J.E., Waugh, W.L., and West, D. (2007) "Principles of emergency management supplement." Emergency Management Public Safety, Public Trust. http://www.iaem.com/publications/documents/PrinciplesofEmergencyManagement.pdf (Accessed February 2, 2013).

Caldwell, S.L. (2013) "Critical infrastructure protection: preliminary observations on DHS efforts to assess chemical security risk and gather feedback on facility outreach." Testimony before the Subcommittee on Environment and the Economy, Committee on Energy and Commerce, House of Representatives.

Caldwell, S.L. (2012) "Critical infrastructure protection: summary of DHS actions to better manage its chemical security program." Testimony before the Subcommittee on Homeland Security, Committee on Appropriations, House of Representatives.

Center for Effective Government. (2013) "Spills and Accidents.” http://www.rtknet.org/db/erns\# (Accessed February 6, 2014).

Department of Homeland Security (DHS). (2012) "Evaluating need to know for ChemicalTerrorism Vulnerability Information (CVI)." dhs.gov, http://www.dhs.gov/evaluatingneed-know-cvi (Accessed February 2, 2013).

DHS. (2011) "Readout of Secretary Napolitano's remarks at the National Private Sector Conference." dhs.gov. http://www.dhs.gov/news/2011/08/03/readout-secretarynapolitanos-remarks-national-private-sector-conference (Accessed February 2, 2013).

DHS. (2008a) "National response framework." dhs.gov , p 5. http://www.fema.gov/pdf/emergency/nrf/nrf-core.pdf (Accessed February 2, 2013). 
DHS. (2008b) "Safeguarding information designated as Chemical-Terrorism Vulnerability Information (CVI): revised procedural model." dhs.gov. http://www.dhs.gov/xlibrary/assets/chemsec_cvi_proceduresmanual.pdf (Accessed February 20, 2013).

Department of Justice (DOJ). (2000) "Assessment of the increased risk of terrorist or other criminal activity associated with posting off-site consequence analysis information on the internet".

Dynes, R.R., Quarantelli, E.L. and Kreps, G.A.. (1972) A perspective on disaster planning. Columbus: Disaster Research Center, Ohio State University.

FEMA. (2012). "Public-private partnership". http://www.fema.gov/public-private-partnerships-0 (Accessed April 4, 2013).

Fugate, C. (2011) "Improving the nation's response to catastrophic disasters: how to minimize costs and streamline our emergency management programs." Testimony before the United States House Transportation and Infrastructure Committee, Subcommittee on Economic Development, Public Buildings, and Emergency Management. http://www.dhs.gov/news/2011/03/30/administrator-craig-fugate-federal-emergencymanagement-agency-transportation-and (Accessed February 20, 2012).

Heritage Foundation (2012). "Fifty terror plots foiled since 9/11: The homegrown threat and the long war on terrorism.” http://www.heritage.org/research/reports/2012/04/fifty-terrorplots-foiled-since-9-11-the-homegrown-threat-and-the-long-war-on-terrorism (Accessed February 6, 2014).

Howe, D (2004) "Planning scenarios", The Homeland Security Council. Accessed February 18, 2012. http://www.voiceoffreedom.com/archives/homelandsecurity/15attacks the hawiaa_disclosure.htm.

Kapucu, N. and Garayev, V. (2001) "Collaborative decision-making in emergency and disaster management.” International Journal of Public Administration, Vol. 34: p 369.

KPMG. (2010) "The outlook for the US chemical industry." https://www.kpmg.com/US/en/IssuesAndInsights/ArticlesPublications/Documents/uschemical-industry-outlook.pdf (Accessed February 19, 2013).

Lippin, T. M., McQuiston, T.H., Bradley-Bull, K, Burns-Johnson, T., Cook, L., Gill, M.L., Howard, D., Seymour, T.A., Stephens, D., Williams, B.K. (2006) "Chemical plants remain vulnerable to terrorists: a call to action. Environ Health Perspectives, Vol. 114 no. 9: 1307-11. http://www.ncbi.nlm.nih.gov/pmc/articles/PMC1570090/\#b2-ehp0114001307 (Accessed February 8, 2013). 
National Consortium for the Study of Terrorism and Responses to Terrorism (START). (2012) Global Terrorism Database [Data file]. http://www.start.umd.edu\$/gtd (Accessed February 21, 2013).

National Infrastructure Protection Plan. (2009) http://www.dhs.gov/national-infrastructureprotection-plan (Accessed April 28, 2013).

Orum, P. (2008) “Chemical security 101: What you don't have can't leak, or be blown up by terrorists," Center for American Progress, p 3. http://www.americanprogress.org/wpcontent/uploads/issues/2008/11/pdf/chemical_security.pdf (Accessed January 24, 2013).

Perry, R.W., and Lindell, M. (2006) Emergency planning. New York: Wiley.

Sadiq, A.A. (Forthcoming) "Chemical Sector Security: Risks, Vulnerabilities, and Chemical Industry Representatives' Perspectives on CFATS.” Risk, Hazards \& Crisis in Public Policy.

Sadiq, A.A. and McCreight, R. (2013) “Assessing the Chemical Facility Anti-Terrorism Standards after 5 years: Achievements, Challenges, and Risks Ahead.” Journal of Homeland Security and Emergency Management. Volume 10, Issue 1, Pages 1-18, ISSN (Online) 1547-7355, ISSN (Print) 2194-6361, DOI: 10.1515/jhsem-2012-0040, July 2013

Schierow, L.J. (2006) “Chemical facility security.” Congressional Research Service. http://www.fas.org/sgp/crs/homesec/RL31530.pdf (Accessed January 31, 2013).

Shea, D.A. (2012) "Chemical facility security: issues and options for the $112^{\text {th }}$ Congress." $C R S$ Report for Congress.

Shea, D.A. (2009) "RMP facilities in the United States as of December 2009". Congressional Research Service.

Simmins, C. (2012) "Private Donations for Hurricane Sandy Relief Fall Short". Yahoo.com. http://news.yahoo.com/private-donations-hurricane-sandy-relief-fall-short163500875.html (Accessed April 4, 2013).

Spaulding, S. and Wulf, D. (2012) Statement for the Record Before the House Committee on Appropriations, Subcommittee on Homeland Security, United States House of Representatives.

Spellman, F.R. and Bieber, R.M. (2009) Chemical infrastructure protection \& homeland security. Lanham, Maryland: Government Institutes.

Stephenson, J.B. (2005) "Federal and industry efforts are addressing security issues at chemical facilities, but additional action is needed." Testimony Before the Committee on Homeland Security and Governmental Affairs, U.S. Senate. http://www.gao.gov/assets/120/111602.pdf (Accessed January 31, 2013). 
The 9/11 Commission Report. (2004). http://www.9-11commission.gov/report/911Report.pdf, (Accessed February 2, 2013).

The World Bank. (2013) "PPP in infrastructure resource center" http://ppp.worldbank.org/public-private-partnership/overview/what-are-public-privatepartnerships (Accessed on May 1, 2013).

Viscusi, W.K. (2009) "Valuing risk of death from terrorism and natural disasters." Journal of Risk and Uncertainty. 38: 191-213.

Waugh, W.L. and Sadiq, A.A. (2011) "Professional education for emergency managers." Journal of Homeland Security and Emergency Management, Vol 8, No. 1.

Waugh, W.L. and Streib, G. (2006) "Collaboration and leadership for effective emergency management". Public Administration Review.

Wayne B. Blanchard, Lucien G. Canton, Carol L. Cwiak, Kay C. Goss, David A. McEntire, Lee Newsome, Michael D. Selves, Eric A. Sorchik, Kim Stenson, James E. Turner, William L. Waugh, Dewayne West. (2007) "Principles of emergency management supplement." Emergency Management Public Safety, Public Trust, p 4. Accessed February 2, 2013, http://www.iaem.com/publications/documents/PrinciplesofEmergencyManagement.pdf. 